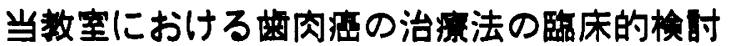

\author{
神谷祐 司・下楖和 雄・狙田進 \\ 吉田茂: 服部吉幸・小牧完二 \\ 牧野也・深野英夫・河合幹
}

\section{The clinical study on treatment of gum carcinoma in our department}

\author{
Yuji KamiYa - Kazuo Shimozato - Susumu = IIDA \\ Shigeru Yoshida - Yoshiyuki Hattori $\cdot$ Kanji KomakI \\ Shinya Makino - Hideo Fukano - Tsuyoshi KawaI
}

\begin{abstract}
The clinical study on 24 cases of gum carcinoma treated in our department from April 1982 to March 1986 was presented. Of the 24 cases, 3 cases were palliative, and 21 cases were surgically treated. Among the 21 surgical cases, radical neck dissection was performed in 18 cases and in 9 cases the lymph-nodes were proven positive.

The ratio of metastasis to neck lymph nodes was $3 / 8$ (40\%) from the maxilla, $5 / 6(30 \%)$ from the mandible. The percentages of cases were neck dissection was performed, was $60 \%$ in the former, $80 \%$ in the latter. In the mandible, segmental and marginal resection was performed in 10 cases and 4 cases respectively.

It was concluded that an extra-oral approach to mandibular gum carcinoma requires neck dissection, especially modified neck dissection or supra-omohyoid neck dissection.
\end{abstract}

Key words: Gum carcinoma, Cervical metastasis, Radical neck dissection

\section{緒言}

蒾肉癌は口腔癌のなかです比較的多くみられ，その出 現頻度は各施設によって多少異なるが，一般に口腔癌の 10〜30\%といわれている1-3)， 口腔外科からの報告では， 27〜 48\%とい5高い値の報告もあり ${ }^{6 \sim 8)}$ ， 口腔外科に拧 ける齿肉癌の出現頻度は他科の施設より高いよ5であ る.

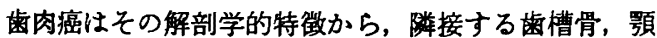
骨へ早期に浸潤し，放射線治療効果の判定が因難である ことも相俟って，その治療法には外科的治療がよく選択 される。また，手術に祭しては，特に下頻において手術 手技上，頼下部の経皮ルートを使用するため，上頸部の

受知学院大学荤部第 2 口腔外科学教室

(主任：河合 幹教授)

The Second Department of Oral and Maxillofacial Surgery, School of Dentistry, Aichi-Gakuin University (Chief: Prof. Tsuyoshi Kawai)

受付日：昭和62年 1 月 9 日
リンパ流を破壊する可能性が大きくなるので頸部郭清術 を併せて施行することが多くなり，その結果として予防 的頸部郭清術の率か高くなるか，予防的頸部郭清術につ

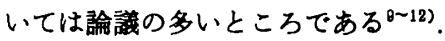

今回われわれは，歯肉癌の一次治療症例24例の䣒床的 観察を行い, 臨床的顓部転移と組織学的頸部転移を比較 し，歯肉癌の頙部郭清術について検討したので報告する.

\section{対 象 症 例}

対象とした症例は， 1982 年 4 月より 1986 年 3 月まで の 4 年間に，要知学院大学齿学部第 2 口腔外科で治療を 行った口腔癌73例のらちの歯肉癌一次症例 24 例である゙ （表 1 ）.24例の内訳は，年龄は18歳から86歳，性別は男 性10例，女性14例，上下額別では上額 8 例，下顥16例， TNM 分類は表 2 のとおりであった。 なお，TNM 分類 は，1978年の UICC 分類 ${ }^{(3)}$ に従い, 頸部リンパ節は图 1 のごとく分類した ${ }^{14)}$. 日本頭頸部尰湯学会による頭頸 部癌取り扱い規約の分類 ${ }^{15)}$ とは, 副神経リンパ節, 側深 顓リンパ節および鎖骨上リンバ節で異なるのみである。 


\section{研 究 結 果}

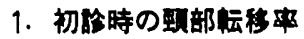

初粀時の到部枟移は，衣了，4のごとくである。 すな

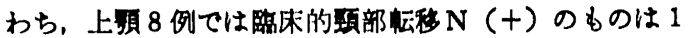
例で 1/8 (13\%)であった。 また下䪷16例では， $N(+)$ のものは 4 例で 1/4 (25\%) であった。 また，これを賉

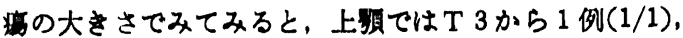
下影ではT 2 から 1 例 $(1 / 7) ， \mathrm{~T} 3$ から 2 例(2/4), T4

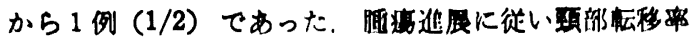
が高くなっている。

\section{2. 治㳟法と予啳}

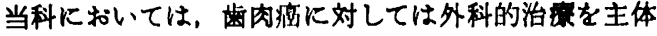
とし，全身状的中年路的問題から手術䢔応のないるのに は，二次選択として放射線治㞠を主体とした治行を行

表 1 口腔癌一次症例73例の部位别分類 (1982. 4 1986.3)

\begin{tabular}{|c|c|c|c|}
\hline & & 症例 & $\%$ \\
\hline 㐘 & 肉 & 24 & 32.9 \\
\hline 舌 & & 18 & 24. 7 \\
\hline 口 腔 & 底 & 10 & 13. 2 \\
\hline 煩 粘 & 膜 & 6 & 8.2 \\
\hline 日後三 & 角 & 5 & 6.8 \\
\hline 上 䫚 & 洞 & 4 & 5.5 \\
\hline 下 & 唇 & 2 & 2.7 \\
\hline 扁 & 桃 & 2 & 2.7 \\
\hline 澦 下 & 腺 & 1 & 1. 4 \\
\hline その & 他 & 1 & 1.4 \\
\hline 計 & & 73 & \\
\hline
\end{tabular}

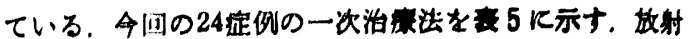

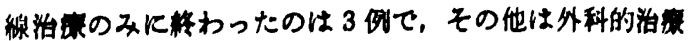

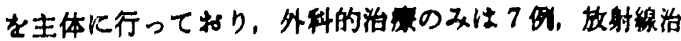

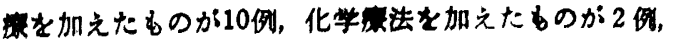

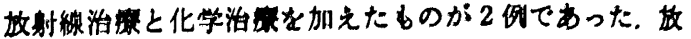
射線治策を加えたるのは，全例で12倵で，このろち街前 照射を行ったものは 6 侧で，平均 18 Gy であった，

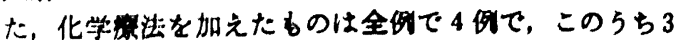
例はペフロコインンナシスフラチナム，1 侽は $5 \mathrm{Fu}+$

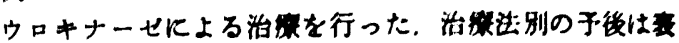
5 のことく，外科的治策を行えなかった 3 例恃全何死亡 （原病死 2 例，他病死 1 例）しているか，その他は全例 拪登なく生存している。

\section{3. 㻍部部清䘕について}

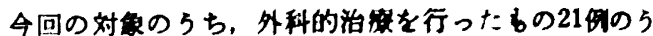

表 2 肉瘦 24 例の内わけ

\begin{tabular}{|c|c|c|c|c|c|}
\hline 名前 & 年龄 & 性 & 部位 & TNM & 予 \\
\hline & 56 & 女 & 下顎 & 200 & 48か月生 \\
\hline & 69 & 男 & 上䂓 & 200 & 原病死 \\
\hline & 86 & 女 & 下額 & 310 & 原病死 \\
\hline & 68 & 女 & 下䫑 & 430 & 40か月生 \\
\hline & 65 & 女 & 上顎 & 200 & 40か月生 \\
\hline & 68 & 男 & 下顎 & 100 & 他病死 \\
\hline & 78 & 女 & 上䫟 & 200 & 34か月生 \\
\hline & 18 & 女 & 上䅡 & 200 & 27か月生 \\
\hline & 55 & 女 & 下顎 & 300 & 27か月生 \\
\hline & 74 & 男 & 下顎 & 100 & 25か月生 \\
\hline & 33 & 男 & 上䫑 & 200 & 25か月生 \\
\hline & 76 & 男 & 下影 & 200 & 24か月生 \\
\hline
\end{tabular}

\begin{tabular}{|c|c|c|c|c|c|}
\hline 名前 & 年期 & 性 & 部位 & TNM & 子 \\
\hline & 56 & 女 & 上䫑 & 310 & 23か月生 \\
\hline & 72 & 女 & 下㯋 & 200 & 22か月生 \\
\hline & 62 & 男 & 下預 & 100 & 18か月生 \\
\hline & 66 & 男 & 下頭 & 200 & 17か月生 \\
\hline & 75 & 女 & 下㯋 & 220 & 15か月生 \\
\hline & 32 & 男 & 下額 & 200 & 15か月生 \\
\hline & 56 & 男 & 下影 & 300 & 13か月生 \\
\hline & 48 & 女 & 下預 & 310 & 12 只生 \\
\hline & 68 & 女 & 上䫅 & 400 & 10か月生 \\
\hline & 42 & 女 & 下颖 & 200 & 9 か月生 \\
\hline & 50 & 男 & 上預 & 200 & 9 か月生 \\
\hline & 63 & 女 & 下額 & 400 & 8 只月生 \\
\hline
\end{tabular}




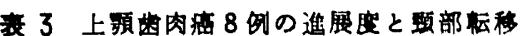

\begin{tabular}{l|l|l|l|l|l}
\hline \multirow{2}{*}{} & \multicolumn{5}{|c|}{$\mathrm{N}$} \\
\cline { 2 - 5 } $\mathrm{T}$ & 0 & 1 & 2 & 3 \\
\hline \multirow{3}{*}{$\mathrm{T}$} & 1 & & & & \\
& 2 & 6 & & & \\
& 3 & & 1 & & \\
& 4 & 1 & & & \\
\hline
\end{tabular}

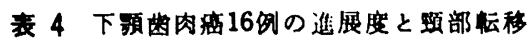

\begin{tabular}{|c|c|c|c|c|c|}
\hline & & \multicolumn{4}{|c|}{$\mathbf{N}$} \\
\hline & & 0 & 1 & 2 & 3 \\
\hline \multirow{4}{*}{$\mathrm{T}$} & 1 & 3 & \multirow{4}{*}{2} & \multirow{4}{*}{1} & \\
\hline & 2 & 6 & & & \\
\hline & 3 & 2 & & & \\
\hline & 4 & 1 & & & 1 \\
\hline
\end{tabular}

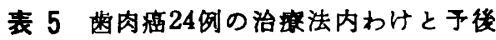

\begin{tabular}{l|r|r}
\hline 治 症 法 & 症 例 数 & 生 存 数 \\
\hline $\mathbf{R}$ & 3 & 0 \\
$\mathrm{~S}$ & 7 & 7 \\
$\mathrm{~S}+\mathrm{R}$ & 10 & 10 \\
$\mathrm{~S}+\mathrm{C}$ & 2 & 2 \\
$\mathrm{~S}+\mathrm{R}+\mathrm{C}$ & 2 & 2 \\
\hline
\end{tabular}

$\mathbf{R}$ : 放射線家法

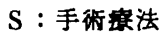

C : 化学暴法

ち，18例に頚部郭清術が施行されている．その施行時期 は, 原発巣の切除と同時に行った頸部郭清術（一次的頊 部郭清術）は15例で，上額 3 例，下額12例であった（表 6). これらのらちN (+) 例には根本的項部郭清術が, N（一）例には部分的頙部郭清術または機能的頸部郭清 術が施行されている，後発転移に対し行った顒部郭清術 （二次的頻部郭清術）は 3 例で，上顜 2 例，下顥 1 例で あり，全例根本的頸部郭清術が施行された。

原発巣の切除とともに行った頸部郭清術15例を，上下 䅡別と臨床的频部転移とで観察したものが表 7 である.

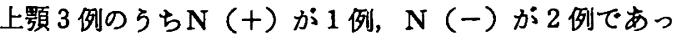

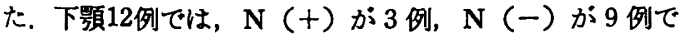
あった。すなわち，下顎の頚部郭清術のらち 9 例 (75 \%) に予防的頉部郭清術を施行したことになる。なお， 臨床的顠部転移 $\mathrm{N}$ と組織学的頸部転移 PN の関係は表 8 のごとくで, 各症例についてこの時点までの全経過を 通じての項部リンパ節転移検出に関する 正診率は $93 \%$ (14/15), 䛇診率 $7 \%(1 / 15)$ 偽陰性であった。

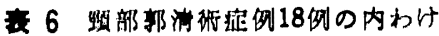

\begin{tabular}{|c|c|c|c|}
\hline 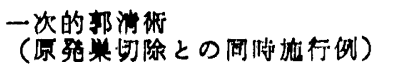 & 15例 & $\begin{array}{l}\text { 上䫓 } \\
\text { 下影 }\end{array}$ & $\begin{array}{l}3 \text { 侧 } \\
12 \text { 侧 }\end{array}$ \\
\hline 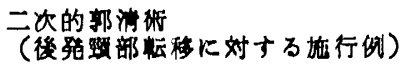 & 1 & $\begin{array}{l}\text { 上嶆 } \\
\text { 下颙 }\end{array}$ & $\begin{array}{l}2 \text { 例 } \\
1 \text { 侧 }\end{array}$ \\
\hline
\end{tabular}

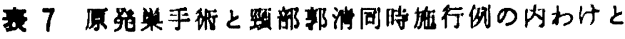

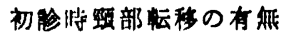

\begin{tabular}{|c|c|c|}
\hline & $-\mathrm{N}(+)$ & 1 例 \\
\hline & $-\mathbf{N}(-)$ & 2 例 \\
\hline & -1 & 3 例 \\
\hline & $N(-)$ & 9 例 (PN (t) 1$)$ \\
\hline
\end{tabular}

这：PN-病理組織診で $\mathrm{N}(+)$

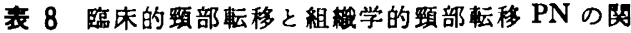
係

$$
\begin{aligned}
& \mathbf{N}(+)<\begin{array}{ll}
\mathrm{PN}(+) & 4 \text { 例 } \\
\mathrm{PN}(-) & 0
\end{array} \\
& \mathrm{~N}(-)<\begin{array}{ll}
\mathrm{PN}(+) & 1 \text { 例 } \\
\mathrm{PN}(-) & 10 \text { 例 }
\end{array}
\end{aligned}
$$

表 9 病理組繥診での顒部夽移例 9 例の転移部位内

\begin{tabular}{|c|c|c|}
\hline 転移りンハ、節 & 症 例 & 数 \\
\hline オトガイ下 & 1 & \\
\hline 額 下 & 7 & \\
\hline 上 深 頸 & 4 & \\
\hline 中 深 頸 & 3 & \\
\hline 下 深 頚 & 1 & \\
\hline
\end{tabular}
わけ

（2か所以上転移例があるため症例数重襩）

硕部郭清術施行18例中, 二次的顆部郭清術す含め PN （十）は9 例で，その転移部位を表 9 に示す。各部位に 重複したものも含め転移部位は䫓下リンパ節 7 例, 上深 頸リンパ節 4 例，中深頸リンパ節 3 例，下深頸リンパ節 1 例，オトガイ下リンパ節 1 例であった. UICC の顥部 リンパ節転移のレペルでは，レベル 1 までが 8 例、レベ ル 2 までが 4 例, レベル 3 までのあのが 4 例であった.

\section{4. 顆部部清術施行來と頸部転移來}

頸部郭清術の施行率と頚部転移率を比較すると, 上頻 は頸部転移率 3/8 (40\%) に対し频部郭清術施行率が 5/8（60\%）とあまり差のない値となったが，下頻では 頸部転移率5/16 (30\%) に対し頸部郭清術施行率 13/16 (80\%) と大きな差を認めた（表10）. 
\#

is

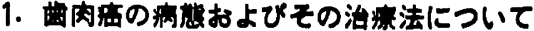

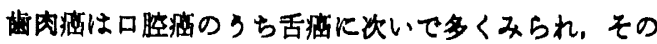
発現频度は口腔癌の10〜30\%年の) といわれている。 この 值は各施設に上ってかなり美がみられるが，一般に口胵

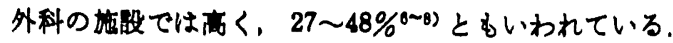
当科に打いては，1982年 4 月から1986年 3 月までの 4 年

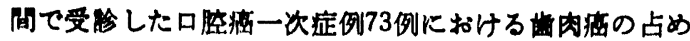
る割合は，24例 (33\%) と最す多く，次いで䗒の18例 (25\%) であった。

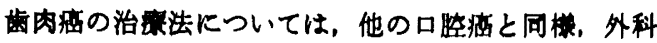

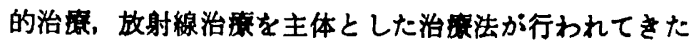

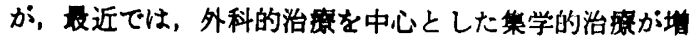

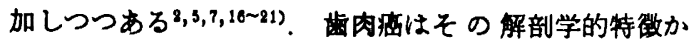
ら容易に歯槽骨，影矛へ進展するので，具吸収を引き起 こしている率は78.2\%")あるいは94.9\%(1) とまでいわれ ている，骨へ漫润した腫埸は，視診，触診，X線診断な

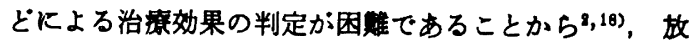
射線治鹿では制御しにくいとされ，さらには，根治が得 られたと考えられた後に放射線性骨壤死を引き起こし， 治療後の経過䠐察を困奞にし，特に下額においてはその 機能形的を保存することが困難となることも少なくな

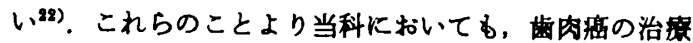
は，外科的治療を主体においており，今回の症例も24例 中21例 $(88 \%)$ 飞外科的治療を加えている．患者の全身 状態および年龄的な問題のため手術の適応とされず，姑 息的放射線治㫫のみを行ったものは 3 侧 (12\%) であっ たが，1 例の他病死を含め全例予後不良である. 外科的 治療を主体に行いえた 21 例は，全例再発むなく生存し ている. 全症例でみると，今のところの局所非再発率は 87.5\%とい5結果を得ているが，症例数も少なく，制察 期間も短い（ 8 か月～ 4 年）ので治㞠成嚗としては確定 的でない.

\section{2. リンパ節転移㴍相について}

齿肉癌の頸部リンバ節への枟移頻度については数多く の報告がある $5,7,20$ 27)，その転移率は多少巽なっている が，30〜50\%といわれ，舌癌のそれよりやや低いよらで ある. また，文献的には上顥歯肉と下影歯肉に分けて述 べているすのもあるが24 27)，上䪽の值は $16.7 \%$ ８0\% と幅広く，各報告の症例数も少ないため，上頻と下頻の 転移率の差は明らかでないわわわれの症例では，上䫑 で40\%，下䫁で30\%の症例が頚部リンパ節に枟移してお。 ク，上下箱合わせてみてみると8/24例 (33\%) の転移を みており，上頻と下䫑では転移率に大きな差はないと考 えている。

次に，歯肉瘦のリンバ節転移部位は，レベル $1,2 k$ 多くみられ，時にレベル3，4までの転移すみられてい

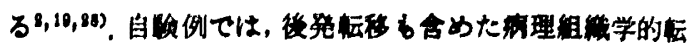
秘陆性の 8 例のろち、レペル 1 までの症例が 2 例，レヘ ル 2 までが 3 侧、レペル 3 までが 3 例で，レヘル 4 まで

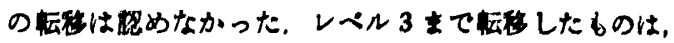

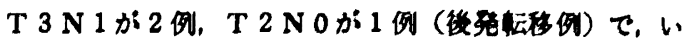

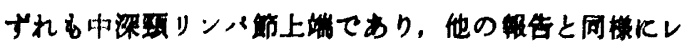
ペル1，2までか5/8侧 (62.5\%) と多く、レベル3ま での轱积は3/8例 (37.5\%) と少なかった。 これらのこ

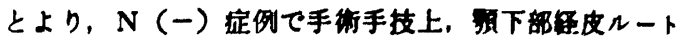

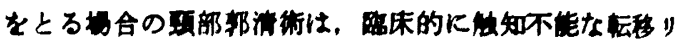
ンく節 (subclinical lymphnode) がったとしてい，好

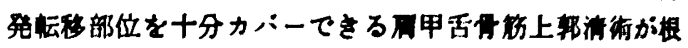
本的而部部清術よりる着当と考えるが，これについては 样しく次で述べる。

\section{3. 正部部清街について}

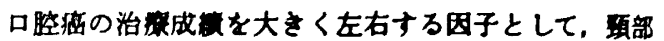
枟移に対与る制御があけられるか，この制㣡の手段に，

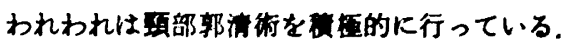

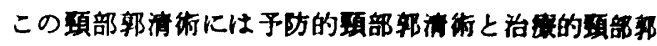

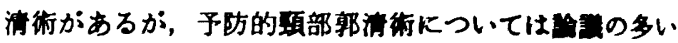

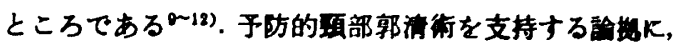
後発枟移リンハ節の凬題がある゙11。これに对してわれわ

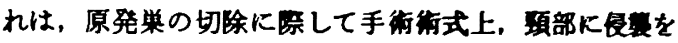

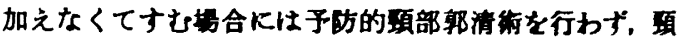

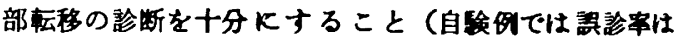

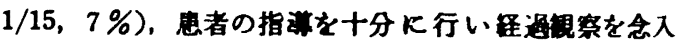
りにナること（当科では少なくとも街後 1 年までは 2 违 に 1 度，5年までは 1 か月に 1 度の睍祭を原䐓としてい

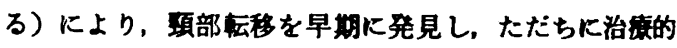
到部部清術を行らこととしており，今までのところ頸部

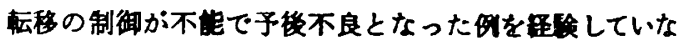
(16).

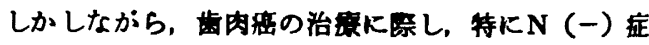
例です下預区域切除や半何切除の時には口整外の頻下部 释皮ルートを使用することがあり，その場合かれわれは

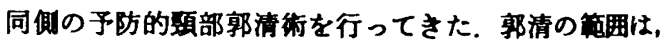

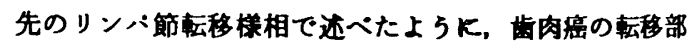
位はレペル1，2K多く，レベル4にはははととみられ ないことより，レヘル3の上半まで，すなわち中深頡り ンハ節下端まで郭㳻できる局甲舌骨算上郭清を主として 選択し，時に原発紧の進展度や浸洞性により機能的項部 郭清術（副神経保存）を行っている。局甲舌骨筋上郭清 は注とんど很後障害を牫すことなく、オトガイ下リンハ 節，䫑下リンハ節，上中深頊リンバ節が郭清でき，歯肉 癌の予防的垔部郭清術には必要樶少限の手術と考えてい る.もちろん, 術中診断は重要で，伝移を筑わせしめる リンバ節を認めたら，ただに治㞠的全靨部郭清に変更 することは当然である ${ }^{20)}$

以上のよ5な方針でわれわれは齿肉癌の治療を行って 


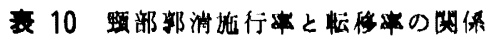

\begin{tabular}{|c|c|c|c|c|}
\hline & & \multicolumn{2}{|c|}{ 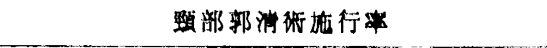 } & \multirow[b]{2}{*}{ 㕬楼秘 $(\%)$} \\
\hline & & 一次的郭消 $(\%)$ & 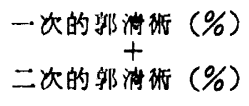 & \\
\hline 上 & 䫑 & $3 / 8(40)$ & $5 / 8(60)$ & $3 / 8(40)$ \\
\hline 下 & 顎 & $12 / 16(80)$ & $13 / 16(80)$ & $5 / 16(30)$ \\
\hline
\end{tabular}

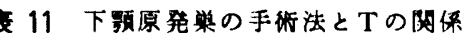

\begin{tabular}{|c|c|c|c|c|}
\hline & 1 & 2 & 3 & 4 \\
\hline 辺椂切除術 & 2 & 2 & & \\
\hline 区域切除行 & & 5 & 3 & 1 \\
\hline
\end{tabular}

きた．根治的治㞠を行いえた 21 例は現在のところ再発を 認めていないか，先に頚部郭清術の項で述べたごとく， 十分な経過钼察と治療的頚部郭清術に上り後発頚部転移 かかなり良好に制御できることを考えると，これらの症 例の5ち，特に予防的项部郭清術を施行した11例に関し ては，靧下部経皮ルートをとらなければ，頸部郭清術を 施行せす経過観察に委ねることができたともいえる．䫅 下部経皮ルートを選択した症例は，上頻の後方進展例に 対して肩甲舌骨筋上郭清術とともに側咽頭部郭清術を行 った 2 例の他はすべて下筫区域切除を行ったものであっ た.

齿肉癌は早期より影骨に浸潤し7,21)，腫瘍の範囲を正 確に診断することはむすかいいといわれている2,30,31). このため，下頻骨に浸潤がみられるものに対し，下額区

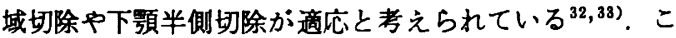
れに関し，下䅡骨漫潤を $\mathbf{X}$ 線学的に，虫喰状，平滑状，

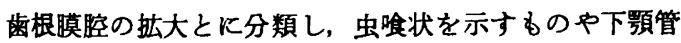
周囲に及ら゙もの以外は辺縁切除にとどめられるとするも $の^{34)}$ ，また，原発腫漡の進展度により区分して，全体の 60\%にあたるT 1，T 2 のほとんどは辺縁切除にとどめ

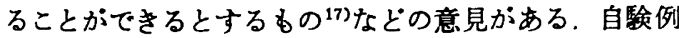
では，下䫚区域切除を行ったものは10例（らちT 2 が 5 例, T 3 が 3 例， T 4 が 2 例) でT 2 の 5 例の 5ち 4 例 はN (一) 症例で予防的新部郭清術を行ったすのであ り，下䪽辺縁切除を行ったものは 4 例（らち T 2 か 2 例， T 1 か 2 例) であった（表11）.あるいは，この下 頧区域切除を行った T 2 の 5 例は辺縁切除で原発の制御 が可能であったのかもしれない，今後，臨床的判断とと bに, 病理組織学的, X線的飞も分検討を加えてゆ き，適正手術範囲を決定してゆきたいと考えている。
結

語

1982年 4 月より1986年 3 月までの 4 年間で妥知学院大 学齿学部第 2 口腔外科にて治療を行った歯肉瘦一次症例 24例に対し，臨床的検討を行い以下の結論を得た。

1. 歯肉滛24例のうちわけは，上頻 8 例，下影16例で， その治療法は放射線治療の及 3 例，外科的治療を加えた もの21例であった。

2. 外科的治療法を加えた例は，現在のところ全例再 発むなく生存しており，外科的治療を中心とした治療が 奻果的と思われた。

3. 外科的治療を行った 21 例のらち 18 例に頚部郭清術 を施行した。 このらち組織学的転移を認めたるのは 9 例 で，その転移リンバ節は，オトガイ下リンバ節 1 例、顥

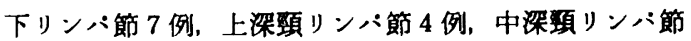
3 例, 下深䫜リンパ節 1 例であった。

4. 頙部リンハ・節への転移率は上頶 $3 / 8(40 \%)$, 下䫑 5/16 (30\%) であった，これに対し頙部郭清術の施行率 は上額5/8 (60\%)，下䫑13/16 (80\%) と，下頑におい て転移率と頸部郭清術施行率に大きな差を認めた。

5. 下影区域切除は 10 例, 下額讱緑切除仕 4 例に施行 された，そして，この区域切除を行5際顥下部経皮ルー 卜を使用することが，下額の顕部郭清術施行率を高的

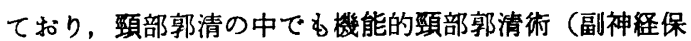
存), 局甲舌骨筋上郭清術の率を高めていることが分っ た.

なお，本論文の要旨は第 4 回口腔畽徥研究会（昭和61 年 1 月，札靦）で発表した。

\section{引用文 献}

1) Shah, J.P., Cendon, R.A., et al.: Carcinoma of the Oral Cavity. Am J Surg 132: 504-507 1976.

2) Cady, B. and Cathin, D.: Epidermoid carcino$\mathrm{ma}$ of the gum. Cancer 23: 551-569 1969.

3) Barthelesen, A., Hansen, H.S., et al.: Radiation 
therapy of squamous carcinoma of the floor of mouth and the lower alveolar ridge. J Laryngol Otol 91: 489-499 1977.

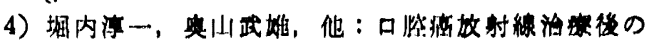
佥期生存例の予後，瘦の路床 30：1855-1860 1984.

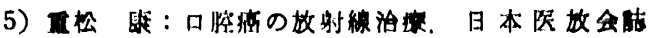
37: 261-285 1977 .

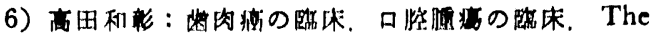
Dental 别册 121-130 1985.

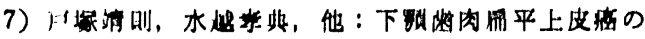

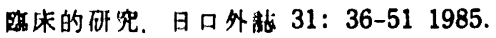

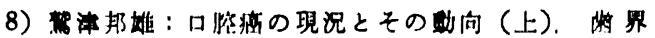
展望 47: 357-367 1976.

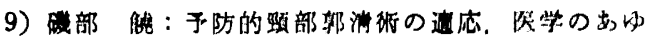
み 103: 567-569 1977.

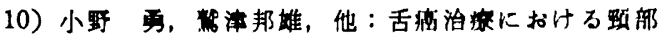

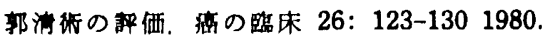

11) Nahum, A.M., Bone, R.C., et al.: The case for elective prophylactic neck dissection. Laryngoscope 87: 588-599 1977

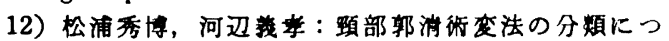
いての检討. 掂の踢床 22: 438-444 1976.

13) UICC: TNM classification of malignant tumors. 3rd Ed, UICC, Geneva, 1978, p 23-26

14）下哏和婎, 吉川則, 他: 颙部部消循症例の予後

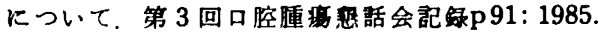

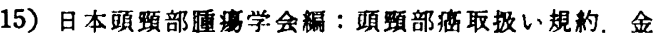

原出版, 東京, 1982, 2-4頁.

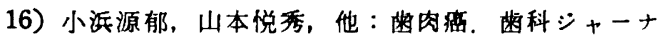
ル 14: 663-676 1981.

17) Byers, R.M., Newman, R., et al.: Results of treatment for Squamous Carcinoma of the Lower Gum. Cancer. 47: 2236-2238 1981.

18）堀内淳一, 奥山武堆, 他: 煩粘膜 - 口腔底・下額

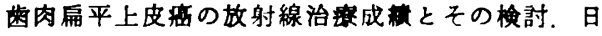
本医故会誌 34：739-751 1974.

19) Backstrom, A., Jakobsson, P.A., et al.: Prognosis of squamous-cell carcinoma of the gums with cytologically verified cervical lymph node metastasis. J Laryngol Otol 89: 391-396 1975.

20）整津邦婎：口腔癌の現況とその動向（下）。茵界

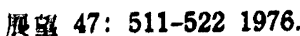

21）武田元一，松本学，他：大吸科大学口腔外科

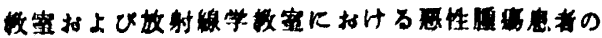

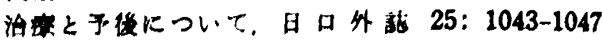
1979.

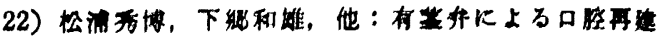

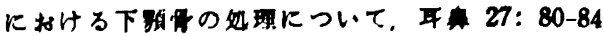
1981.

23) Shear, M., Hawkins, D.M., et al.: The prediction of lymphnode metastasis from oral squamous carcinoma. Cancer 37: 1901-1907 1976.

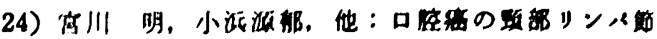

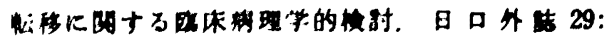
1555-1561 1983.

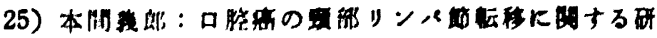
宪。旦口外㥸 28:1667-1684 1982.

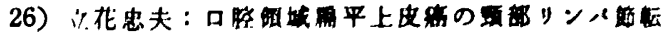

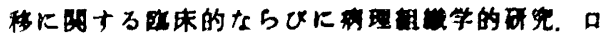
病的 52: 513-536 1985.

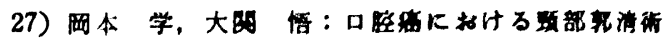
施行例の湌时。目口外志 31:554-562 1985.

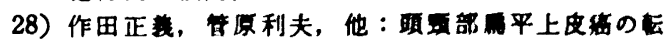

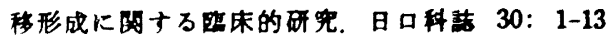
1981.

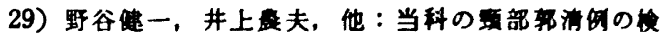
討. 日只外菬 32: 70-81 1986.

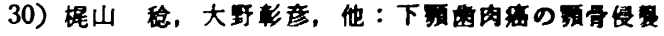
に咸する研究。舟の医床 24：4-10 1978.

31) Swearingen, A.G., Mcgraw, J.P., et al.: Roentgenographic pathologic correlation of carcinoma of the gingiva involving the mandible. Am J Roentogenol 96: 15-18 1966.

32) Byars, L.T.: Extent of mandibular resection for treatment of oral cancer. Arch Surg 70: 914-922 1955.

33) Yonemoto, R.H., Ching, P.T., et al.: The composite operation in cancer of the head and neck (Commando Procedure). 104: 809-813 1972.

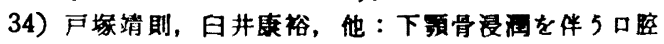

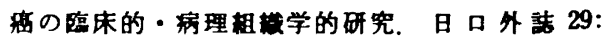
811-819 1983. 